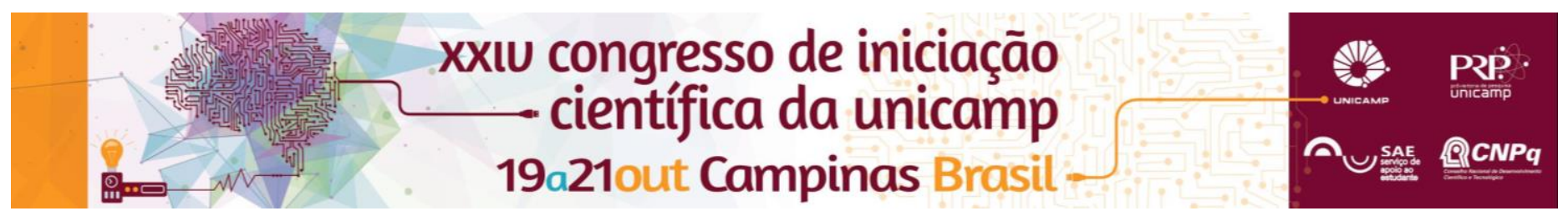

\title{
Construção de Extrusora de Filamento para Impressora 3D
}

\section{Kauane T. Santos, Naiara Risso.}

\section{Resumo}

Durante a primeira etapa do PIBIC-EM, aprendemos montar placas colocando diodo para impedir a ação de AC, Logo após, tivemos aulas para sabermos o que venha a ser o Arduíno. Tivemos aulas também para aprendermos a desenhar no programa (Inkscap), para no final fazer desenhos para imprimir as peças na impressora 3D.E tudo que aprendemos nesta etapa do curso foi para termos uma total noção para montar a impressora. Nesta segunda etapa do PIBIC, montamos a fresadora, a extrusora de filamento e por fim a impressora 3D.

\section{Palavras-chave:}

Impressora 3D, Extrusora de filamento,arduíno.

\section{Introdução}

As aulas de diodos, arduíno, e desenhos foram todas desenvolvidas para no final fazermos a parte elétrica da impressora 3D e as aulas de desenhos para desenhar as peças para a impressão. E a extrusora de filamento para usar na impressora.

O objetivo é Facilitar os processos de prototipagem rápida através da montagem das máquinas.

\section{Resultados e Discussão}

Obtivemos grandes resultados, pois tudo o que fizemos gerou um aperfeiçoamento em cada máquina.

Discutimos sobre as dificuldades que encontramos em montar a parte elétrica, pois foi uma parte muito difícil que com esforço, nós conseguimos montar.

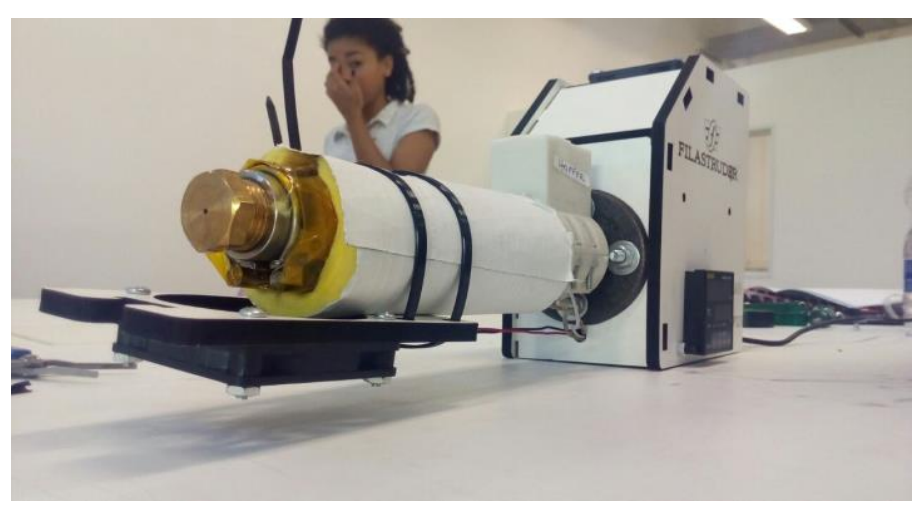

\section{Conclusão}

Iremos usar os filamentos da extrusora para formar as peças da impressora 3d, a única base que necessita para impressão. Cada parte, que fazemos é para benefício para a impressora.

A impressão 3D começa com a criação de um "design 3D". Mais comumente conhecida como modelo $3 \mathrm{D}$, este arquivo é a representação digital do objeto que será impresso. Este arquivo $3 \mathrm{D}$ é então enviado e lido pela impressora 3D. O software interno da impressora 3D envia as instruções para a máquina, que começa a fabricar o objeto, camada por camada.

http://pt.3dilla.com/impressora-3d/funcionamento/

Extrusora de filamento

Tabela 1.

\begin{tabular}{|l|l|l|}
\hline $\begin{array}{l}\text { Aperfeiço } \\
\text { amento }\end{array}$ & $\begin{array}{l}\text { Para } \\
\text { montagem }\end{array}$ & $\begin{array}{l}\text { Da } \\
\text { impressora } \\
\text { 3D }\end{array}$ \\
\hline & & \\
\hline
\end{tabular}

